Acta Poloniae Historica

121, 2020

PL ISSN 0001-6829

\author{
Maciej Falski \\ http://orcid.org/0000-0002-5610-5608 \\ Institute of Western and Southern Slavic Studies \\ University of Warsaw
}

\title{
SLOVENIAN ELITES IN TRIESTE AND THEIR ROLE IN THE FORMATION OF LOCAL COMMUNITIES
}

\begin{abstract}
This text discusses the formation of Slovenian local elites in Trieste in the late nineteenth and early twentieth centuries. A significant part of the analysis presented here concerns the habitus of the elite and the attitudes expressed through the significance they attached to being members of the elite. Drawing on the discourses presented in the Slovenian and Croatian press published in Trieste, as well as biographical sources, this article outlines the vision of society held by the political leaders of the local community. It emphasises how the elites gave expression to their habitus in the public sphere through a variety of institutional activities. I argue that the life of the Slovenian politician and social activist Ivan Nabergoj, a figure central to this text, constitutes an ideal-type committed biography. In conclusion, I address the relationship between the elites and the surrounding community, arguing that elites were representatives of the community while also determining the forms of group belonging by their shaping of mechanisms of consolidation. In this article, I also consider the particularities of the political conditions of Slovenians living in the Slavic-Italian borderlands.
\end{abstract}

Keywords: Trieste, Ivan Nabergoj, local elites, Slavic elites, habitus, Slovenian culture

\section{I \\ INTRODUCTION}

This text describes the formation of Slovenian local elites in Trieste using a framework that draws on the concept of habitus. I examine their role in the formation of a Slovenian political community on the local level. This question is related to the broader issue of the growing influence of nationalism in the public sphere and the emergence of national identity as the dominant mode of identification in the 
second half of the nineteenth century. In the case of the Habsburg monarchy, this marked the decline of the idea of the empire as an inclusive political order and a shift towards the nation-state. What is particularly interesting is how this process played out at the local level in communities that were not directly connected to the centres of nation-centred politics and what forms it took in spaces inhabited by two or more ethnic groups, a situation that was more the norm than the exception in the Habsburg monarchy. The Slovenian case is especially noteworthy because, firstly, Slovenian political projects emerged almost exclusively in spaces that were shared with other ethnic groups that enjoyed greater political, economic and social status (Italians in Trieste and the Austrian Littoral, Germans in Carinthia and Styria); and secondly, because the Slovenian territories were administratively divided, a situation that increased the significance of localness and regional differences. ${ }^{1}$

II

\section{LOCAL ELITES}

The question of elites can be examined from a variety of perspectives. What I propose is an approach that adopts a framework based on Pierre Bourdieu's concept of habitus, while also taking into account the significance of praxis. The central question focuses on what it meant to be a member of the elite and how membership in the elite was reflected in social practice. The article concentrates on local elites, the subject of this special issue. I understand local elites to be members of those groups who possessed social, political, and economic capital in smaller localities throughout the Habsburg monarchy. My analysis thus consciously omits the metropolitan centres of Vienna and Budapest, while it also distances itself at the outset from the concept of national elites. The local dimension means that a social history perspective becomes particularly relevant, allowing us to draw on the analytical tools and related disciplines that enable a more

${ }^{1}$ For a general overview of Slovenian political programmes and the specificities of the Slovenian case within the Habsburg monarchy, see Antoni Cetnarowicz, 'Słoweńskie programy narodowe do roku 1914', Prace Komisji Środkowoeuropejskiej $P A U$, i (1993), 35-50; id., 'Zjednoczona Słowenia. Z problematyki słoweńskiego ruchu narodowego w połowie XIX wieku', Balcanica Posnaniensia, vi (1993), 23-37; Bogo Grafenauer et al. (eds), Zgodovina Slovencev (Ljubljana, 1979). 
thorough reconstruction of social life from below, revealing more closely the experiences of those involved in society. I am particularly interested in recreating the perspectives of members of this social group, which is why one of the key sources for this study is the Slavic press published in Trieste and, to a lesser degree, in Istria. I will also draw on biographical materials, as they offer additional insight on the social mobility of the key actors involved in Slovenian politics at the turn of the twentieth century. ${ }^{2}$

Following Pierre Bourdieu, I define elites as a particular social class, with the class as a concept treated in the logical sense of the word. Bourdieu wrote that according to his notion of social fields, classes are "sets of agents who occupy similar positions [in the social field] and who, being placed in similar conditions and submitted to similar types of conditioning, have every chance of having similar dispositions and interests, and thus of producing similar practices and adopting similar stances". ${ }^{3}$ There are two aspects of this definition worth highlighting in particular. Firstly, the primary motivation of members of a particular class would thus be maintaining unity and forming a closed group to the exclusion of other, rival formations. What would thus be necessary are universal goals and an expression of common beliefs that would legitimise those goals and class interests. Secondly, another important aspect of social class formation is praxis, i.e. the practical

${ }^{2}$ Trieste has been described as the largest Slovenian city of the late-Habsburg period. This seemingly paradoxical statement refers to the number of inhabitants of the city. According to the census of 1910, Trieste had 230,704 inhabitants, with 142,113 declaring Italian to be their 'language of everyday communication' (Umgangssprache), while 37,063 stated Slovenian, and 9,689 German. Given the term used (everyday language) and the way in which the data was collected, the Austro-Hungarian censuses can offer only an approximation of the number of people belonging to particular national communities. Furthermore, as Ivica Pletikosić has shown, the Trieste district commission most probably manipulated the results of the census, perhaps to the extent that Slovenians were underestimated by 20,000 and Germans by 1,000 . The revised figures would tone down the extent of Italian domination. See Ivica Pletikosić, 'Revizije prebivalstva Trsta iz leta 1910', Annales. Serie Historia et Sociologia, xvi, 2 (2006), 477-82. In the census of 1910, Ljubljana had only 46,630 inhabitants (Igor Vrišer, Razvoj prebivalstva na območju Ljubljane [Ljubljana, 1956], 29), with 33,846 declaring their Umgangssprache to be Slovenian, and 5,950 German (around 14 per cent; see Dragan Matić, Nemci v Ljubljani 1861-1918 [Ljubljana, 2002], 433). This means that the Slovenian population was larger in Trieste than Ljubljana.

${ }^{3}$ Pierre Bourdieu, Language and Symbolic Power, trans. Gino Raymond and Matthew Adamson (Oxford, 1990), 231. 
and performative dimension. A group must generate the conviction that it does indeed exist, while proving capable of imposing the desired reading of its status on other participants of social life. ${ }^{4} \mathrm{~A}$ vital aspect of this is visible and recognisable. Bourdieu states, "to exist socially also means to be perceived, and perceived as distinct". ${ }^{5}$ In this article, I am particularly interested in how group belonging is created and then manifested to maintain the group's sense of difference and the legitimisation of its prestigious social status.

Another question addressed is that of who constituted the elites at the level of local communities? The intuitive answer would involve enumerating the members of 'important' professions, such as lawyers, priests and pastors, doctors, engineers, and teachers. In a more general approach to the question, I propose a twofold definition of local elites. Firstly, they are a group who "possess the crucial elements of social authority", which means that "they exert an influence on the course of almost all events". ${ }^{6}$ In a local community, elites not only control the decision-making process but also determine its values and goals, all the while shaping which attitudes are considered desirable. Elites thus constitute a decisive factor in shaping the trajectory of the community's further development. Secondly - here the echoes of Weber and Bourdieu become particularly apparent - the elites are a group that imposes its perspective on all other members of the community while proving capable of acquiring and maintaining its privileged status. The central focus of this article is on exploring how the elites examined managed to do this.

\section{III}

\section{FOR THE PUBLIC GOOD}

During the parliamentary period in the Habsburg Empire, i.e. from 1861, the habitus of the engaged elites took on precise forms. Members of the elite came to express an imperative for social engagement.

${ }^{4}$ I have described the performative aspects of political action in the public sphere more extensively in Maciej Falski, 'Semiotics of the "Third Force" MOST and the Performative and Visual Dimension of Political Life in the Post-electoral Period in Croatia, 2015', Narodna umjetnost, lvi, 1 (2019), 27-40, https://doi.org/10.15176/vol56no102.

${ }^{5}$ Bourdieu, Language and Symbolic Power, 224.

${ }^{6}$ See Josip Jurčević, 'Upravljačke elite u suvremenoj hrvatskoj povijesti', in Drago Čengić and Ivan Rogić (eds), Upravljačke elite i modernizacija (Zagreb, 2001), 81. 
Thus it was 'inappropriate' to tend only to one's personal affairs and insufficient to simply develop a career in a profession that would automatically signal membership in a socially privileged group. What was increasingly at stake as individuals competed with each other was 'social capital', because this determined how someone was perceived and whether they could gain the trust of the entire community.

Analysis of the local press indicates that being active in the local community was an important measure for how the members of the political elite were perceived generally. What is crucial to note, however, is that the Slovenian and Croatian press in Trieste and Istria emphasised individuals' engagement with the national and Slavic causes, always appreciating this aspect of elites' activities; and not only their involvement in their local communities. One illustration of this is provided by a note describing the events marking the twenty-fifth anniversary of Ivan Nabergoj's (1835-1902) involvement in public life. The celebrations of the activism of this Slovenian politician from Trieste were depicted in an Italian-language Croatian periodical published in Pula in 1891. Nabergoj was described as an "energetic, fair man, ready to make any sacrifice necessary" for the national cause. His distinguished achievements "in defence of the rights of the Slavs of Trieste" were emphasised, as was the fact that even his political adversaries admired his "exceptional fairness and spotless character". ${ }^{7}$ In 1902, following Nabergoj's death, the Ljubljana-based journal Kmetijske in rokodelske novice stressed "the limitless trust which his local countrymen placed in him, electing him in 1865 to the city council and then in 1873 to the national council". His achievements were all the more praiseworthy because he served on both councils for twenty-five years uninterrupted. His obituary also highlighted his economic activities. ${ }^{8}$ Of course, both sources reflected the rhetoric typically associated with anniversary-related texts or obituaries, which are written for exceptional occasions. However, Nabergoj was also described in similar terms during his years as an active politician, as a text in the Triester Tagblatt from 1885 shows, describing his "political virtue, fairness". ${ }^{9}$

7 'L'anniversario politico d'un egregio patriota sloveno', Il Diritto Croato, iii, 15 (1891), 4.

8 'Ivan Nabergoj', Kmetijske in rokodelske novice, xl, 38 (1902), 372.

${ }^{9}$ Cited in Andrej Rahten, Ivan Nabergoj, in Andrej Rahten (ed.), Tvorci slovenske pomorske identitete (Ljubljana, 2010), 168. 
It is worth considering what led to Nabergoj being held in such high regard and how he acquired such an important position in the Slovenian social imagination. I would argue that this was the case because he reflected the habitus typical of local community activists during times of national transformation. He was born in Prosek (Prosecco) near Trieste. ${ }^{10}$ Ivan initially worked on his father's farm and also delivered building materials. He only completed primary education and was subsequently self-taught. He owed his career to his hard work, dedication and resilience, which became evident as he advanced up the political ladder. ${ }^{11}$ His experience was typical of the social trajectory followed by many members of the Slovenian elite as they fought for their places in a field dominated by Italian- and German-speaking groups. This upward mobility was enabled not by inherited titles but by hard-won achievements. Nabergoj's fate can thus be considered a synecdoche for the mobility of Slovenian elites in the Austrian Littoral region. Furthermore, Nabergoj was active in the public sphere, creating institutions that enabled the subsequent accumulation of social capital on the local level. He was one of the founders and chairman, between 1875 and 1891, of the Slovenian political association Edinost (Unity). This was the central organisation for Slovenians from Trieste. He was also co-founder of other organisations, including Slovensko delavsko podporno društvo (The Slovenian Workers' Assistance Association), Kmetijsko društvo za Trst in okolico (The Peasant Society in Trieste and its environs), and Tržaška posojilnica in hranilnica (the Trieste Savings and Credit Society). ${ }^{12} \mathrm{He}$ also had nine children, while his house "was for decades at the heart of the public life of Slovenian politicians in the Trieste region". ${ }^{13}$

Nabergoj's biography is thus marked by being open to the public, meaning that the private sphere was minimised in favour of public activism. This applied both in the temporal dimension, as he dedicated an ever greater portion of his time to public activities, as well as to the spatial dimension, as his domestic realm became an extension of

${ }^{10}$ The basic details of Nabergoj's biography come from: Andrej Rahten, Tvorci slovenske pomorske identitete, 165-70.

${ }^{11}$ For more on the subject of Nabergoj's political career, with a particular focus on its local dimensions, see Štefan Čok, 'Ivan Nabergoj, the "never to be" mayor of the Slovenes in Trieste (1873-1897)', Studia Historica Slovenica, xvii, 1 (2017), 65-84.

${ }_{12}$ Rahten, Tvorci slovenske pomorske identitete, 167.

${ }^{13}$ Ibid., 169-70. 
the public sphere. It could be argued that his attitude created an ideal image of a Slovenian who was dedicated to his community. It is also worth stressing that being a member of the Imperial Council meant that he was not only involved in national politics but was also - and primarily - engaged in the local community. Since the provincial and urban councils of Trieste were dominated by Italians, Slovenians found it very difficult to push through their demands with respect to the equal status of Slovenian in education and administrative matters. Thanks to Nabergoj, and later other politicians who also had a voice at the highest level, Slovenians managed to secure some concessions. ${ }^{14}$ It should also be noted that Nabergoj's activities were focused on those fields that determined the economic and social standing of a group (agriculture, credit and loans, social assistance, and education). The fruits of his labour were evident in various aspects of everyday life and not only in the political sphere. The life of Nabergoj was the most significant example of the commitment of local elites, as his activity was of a pioneer nature in various aspects. However, it can be seen as a model for the elites' habitus, demonstrating a tendency toward public engagement and reducing the separation between the public and the private. ${ }^{15}$

Another interesting phenomenon concerns the mutual relations between young Slovenian elites and the local Slovenian community in Trieste. It could be argued that elites not only emerged from this latter group, taking on leading roles within its decision-making processes, but they were indeed constitutive of this group, as they ensured that it build up permanent reserves of capital. Two organisations that Nabergoj co-founded offer an illustration of this. In 1886, he and a second Slovenian deputy in Vienna, Josip Vošnjak, laid the foundations for a financial institution for Slovenians in Trieste. As chairman of the Edinost association, he arranged a founding meeting that took place symbolically - in the Slovenian reading room in Trieste. The statute of what five years later became the Slovenian Savings and Credit Society was ratified at this meeting. ${ }^{16}$ The aim of this institution was

${ }^{14}$ Peter Rustja, Otokar Rybář v dunajskem parlamentu, i (Trst, 2001), 16.

${ }^{15}$ For more examples of elites' involvement, see Maciej Falski, 'Czytanie i ontologia narodu. Chorwacki i słoweński ruch czytelniany w drugiej połowie XIX wieku', in Ewa Łukaszyk and Krystyna Wierzbicka-Trwoga (eds), Niewłasne lektury. Od pisarstwa w języku wyuczonym do wielości kultur czytania (Warszawa, 2018), 95-114.

${ }^{16}$ See 'O tržaški posojilnici in hranilnici', Edinost, xxix, 3 (1904), 2. 
not only to satisfy financial needs but also, as Milan Pahor notes, to offer affirmation of Slovenians' achievements in the public sphere and institutional realm. For example, ensuring that the courts and police would correspond with the management of the Society in Slovenian, its working language as laid out in the statute, was a long and winding process. ${ }^{17}$ What was important, as the daily Edinost noted in 1901, was that this institution was colloquially known as the 'Slovenian society'. ${ }^{18}$ Edinost also published regular reports on the activities of the 'Slovenian society', which were often accompanied by affirmative statements regarding the successes of Slovenians in Trieste. Meanwhile, the Peasant Society in Trieste and its Environs was founded in 1894 in response to the difficulties Slovenians faced in exerting influence on the agricultural society that was founded in 1857 (Società di orticultura del Litorale, later Società agraria di Trieste). Despite Slovenians' involvement, Italian interests prevailed, including in its Italian-language periodical. ${ }^{19}$ While the aim of peasant organisations was "to encourage peasants to adopt and implement superior and technologically-advanced modes of production", ${ }^{20}$ these societies also served a community-forming function that enabled, on the one hand, the institutionalisation of national life, while on the other accumulating social capital and thus improving the standing of a particular group in the competition for status and resources.

In both of the cases described above, the involvement of local elites that had emerged from their community was decisive. Ivan Nabergoj played a particularly important role thanks to the political functions he performed on the local, regional and national levels. As Peter Rustja argues, it was Nabergoj's electoral successes that ensured that "the Slovenian presence in Trieste developed organised structures likewise beyond the reading rooms in a relatively short time". ${ }^{21}$ Owing to his

${ }^{17}$ Milan Pahor, 'Ob stoletnici začetka delovanja tržaške posojilnice in hranilnice', Annales. Series historia et sociologia, ii, 2 (1992), 282.

18 See Pahor, 'Ob stoletnici', 282.

19 Vlado Valenčič, 'Organizacije za napredek agrarne proizvodnje, specialno šolstvo in strokovna literatura', in Pavle Blaznik, Bogo Grafenaure, and Sergij Vilfan (eds), Gospodarska in družbena zgodovina Slovencev. Zgodovina agrarnih panog. Agrarno gospodarstvo, i (Slovenije, 1970), 529.

${ }^{20}$ Valenčič, 'Organizacije za napredek', 523.

${ }^{21}$ Peter Rustja, Med Trstom in Dunajem. Ivan Nabergoj $v$ avstrijskem državnem zboru (1873-1897) (Trst, 1999), 25. 
position, he was able to inspire the Slovenian community's public activities effectively, while also exerting an influence that ensured that the societies could be officially registered. During the initial period, Slovenian national identity was primarily affirmed through activities in reading rooms. They provided the central location for performing Slovenianness, as they provided a stage for the performative consolidation of a community. ${ }^{22}$ They played an indisputably important role as clubs that focused on local life, but the reading rooms could not provide the foundations for broader political and economic activities. It was only a political organisation like Edinost, which Nabergoj co-founded, that could become an institution that represented local Slovenians.

IV

\section{TO ENLIGHTEN AND ORGANISE}

As was noted with no small amount of pathos in the first issue of the daily newspaper Edinost, which was associated with the eponymous organisation, "patriotic men created for the entire region the political association Edinost which will defend national rights and whose purpose is to educate and ensure the prosperity of the entire region". ${ }^{23}$ Two things here are particularly relevant in the context of this article. The first is evidence of the crucial role played by local elites in the politicisation of the population. It was 'patriotic men' (the exclusion of women from the political realm should also be noted) who took the initiative and played a decisive role. Both literally and figuratively, they gave voice to those who were denied one. The newspaper Edinost was established to provide a tribune for Slovenian interests, but elites still forged the language of the public debate and issued postulates that were important for the group that they represented. What I have in mind here is not only the importance of discourse as a means of articulating ideas, but also of language in a rather literal sense. Throughout his time as a political activist, Nabergoj called for the protection of the rights of users of Slovenian and ensured that Slovenian was accepted in official communications

${ }^{22}$ For more on the significance of the reading room for the local population, see Maciej Falski, 'Czytanie i ontologia narodu'.

23 'Resna beseda okoličanom', Edinost, i, 1 (1876), 1-2. 
and education. ${ }^{24}$ The task of these 'patriotic men' - the elites - was to shape the discourse and thus, the political and cultural imagination of the group, as they were products of discourse. Nabergoj's activities were focused completely on this. At the same time, the above-described phenomena also draw attention to the regular references to localness, both in the Edinost newspaper and in Nabergoj's own statements. The article from the first issue of Edinost bore the headline 'Resna beseda okoličanom' (An important speech for residents of the region), with the term 'region' being important in the discourse. References to the local Slovenian community were particularly prominent, even while national consciousness was also stressed. This might have been a result of the peculiarities of the administrative division of the Slovenian lands. Calls to create a single Slovenian territorial unit were never realised during the Habsburg period; thus the Slovenian population was split across several historical territories, with each of these crown lands (Kronland) enjoying equal status. Trieste and its environs were part of the Austrian Littoral (Österreichisches Küstenland), although the city and its surroundings formed a separate Kronland. This meant that Slovenian administrative and political life were primarily conducted within particular provinces, a situation that increased the sense of separateness.

The local dimension was thus of greater significance than was the case with other groups living within the same administrative region. In Nabergoj's political biography, the local dimension was profoundly important, and this fact formed part of a feedback loop: he was from the area around Trieste, which is why he was elected to represent the local Slovenian population, while his public roles, in turn, acted as a constitutive factor in the formation of the Slovenian community on the broader local level, ensuring that they became a consolidated group that expressed itself politically. The "okoličani", i.e. those living in the suburbs and environs around the city that were part of Trieste province, were the main focus of Slovenian elites' activities and thus constituted an emergent subject. In an appeal published in Edinost in 1878, it was stated explicitly that the eponymous political organisation aimed to "defend national rights" and "educate the peasant population". ${ }^{25}$

${ }^{24}$ The language issue was often mentioned in Ivan Nabergoj's speeches. See the selection of his public statements and speeches in Rustja, Med Trstom in Dunajem, 87-117.

25 'Poziv', Edinost, iii, 14 (1878), 1. 
Its objective, then, was to improve the group's status and 'raise its consciousness', which can be understood in terms of encouraging participation in the public sphere. The subsequent issue of the periodical was critical of the unwillingness of Slovenians living around Trieste to ensure that their children were educated beyond primary level. "There are so many wealthy people living in the area who could afford to send their sons to higher and middle schools, yet they never consider the option. Where will we find educated people in the region and who will represent it in the councils? It certainly will not be an 'okoličan', if things carry on the way they are" ${ }^{26}$ What is interesting here is that the emphasis was not placed on education itself as a means of self-improvement, but on the particular needs relating to political representation and the political struggle that had no chance of success without suitably qualified personnel. What appeared in Edinost, then, was a call to create elites who would be a product of their own social group and who would enjoy equal rights and status as they entered the political sphere.

Emblematic of this was Ivan Nabergoj, a man from the 'provinces' (in reality, from the suburbs of Trieste) who made a move towards the centre and claimed a place among the ruling elites. His pre-election manifesto of 1877 stated:

Electors of the 6th district - think carefully about who you will elect; if you do not choose a countryman who has already done so much for the district, who promised to lower taxes in the district and kept his word, who has spoken out so often in the interests of his district ... then you will be judged by the Slovenian nation. ... Vote unanimously so that you can put to shame any Italian ${ }^{27}$ aspirations and thus prove that a powerful Slovenian people inhabit the district. Leave aside any machinations and plotting, put on a united front, think of your gallant honour and may this guide you through the world. May each and every one of you write the name Ivan Nabergoj on your ballot papers. In doing so, you will shame our enemies and put them in the shade. ${ }^{28}$

26 'Velika nemarnost', Edinost, iii, 15 (1878), 3.

${ }^{27}$ In the original, the term 'lahonsko siljenje' was used. The adjective 'lahonski' comes from the archaic word 'Lah', meaning Italian. At the time the periodical was published, it was a pejorative term. The use of this term by contributors to Edinost serves to cast their opponents in a negative light, specifically those responsible for Italy's irredentist policies. The vocabulary and discourse of the Edinost periodical is worthy of a separate study.

28 'Volitev', Edinost, ii, 3 (1877), 3. 
This passage employs a discourse that was typical of the periodical Edinost and other Slavic publications appearing in the Littoral, as it draws on a sense of menace and danger. The language used was to serve the purpose of consolidating the group while also inspiring it to take action. In the Habsburg Empire, the only acceptable solutions were those that remained within the law and used available resources. This explains why activities were concentrated on those fields that influenced the formation of social imaginaries and exerted control over the reproduction of the group, together with its decision-making processes. I have in mind local, provincial, and national government institutions, the press, education, literature and the economy. These issues were addressed very often in Edinost. Nabergoj himself, as mentioned above, was active in each of these fields (except for literature) and sought to inspire members of the Slovenian community to take action in each sphere. The electoral appeal explicitly addressed the issue of representation: genuine local interests could only be represented by 'one of our own' rather than a candidate who had been parachuted in. Deputies became the 'voice' of their voters as they went from the environs and suburbs of Trieste and into the city, claiming a place among the political elites. This is why Čok is right to argue that Nabergoj "was the symbol of the Slovenian political presence in Trieste", ${ }^{29}$ just as the Narodni dom (National Hall) that was later constructed in the centre of the city became the physical manifestation of Slovenianness.

\section{$\mathrm{V}$ \\ INDIFFERENT AND UNDECIDED}

At one extreme of the debate over modern nation-building is the view that nations have existed since the dawn of history, and/or that they were simply awaiting a 'reawakening' or 'rebirth' in the case of those that had experienced political subordination in the nineteenth century. At the other extreme is the opinion that nations are merely symbolic and political constructs that were called into existence through nominative magic, ${ }^{30}$ and the institutionalising and homogenising practices

${ }^{29}$ Čok, 'Ivan Nabergoj', 79.

${ }^{30}$ I refer here to magic as an act of naming that brings social classes into being, as discussed in Bourdieu. See Language and Symbolic Power, 248-52. 
of the nineteenth and twentieth centuries. In this article, I seek to distance myself from this discussion as neither extreme can be upheld. Instead, I would only highlight the political dimensions of ethnic differences, in other words: that moment when differences emerging from the cultural dimension (differences in language, customs and symbolic practices) are employed as arguments in the political realms and/or as tools to legitimise the actions of social actors. In the case of the Slovenians of Trieste and the surrounding region, a particularly interesting phenomenon, mentioned above, was that in the 1870s the sense of community within the Slovenian nation strengthened, while at the same time political practices, economic activities, and other endeavours connected to the consolidation of the group were limited mainly to the local dimension or focused on the highest powers (the Imperial Council and parliament in Vienna). The 'all-Slovenian' level was thus often absent due to the administrative divisions and relative weakness of Ljubljana as a centre. There were no administrative structures that worked on the all-Slovenian level, meaning that it remained an aspiration until the collapse of the Habsburg monarchy, as Ljubljana lacked the necessary prestige to dominate constructions of Slovenianness on the political and cultural levels. ${ }^{31}$

The Slovenian elites from the Trieste region presented and cocreated the group, defining its objectives and setting its discourse. From the late 1860 s on, as mentioned above, the sense that the interests of the Slovenian population were under threat in the Austrian-Italian borderlands was typical at the time and strengthened by the media. ${ }^{32}$ Lewis Coser has argued that when a group senses that it is under threat, it places significant demands on its members, and in particular its public representatives. ${ }^{33}$ Where there is inter-group competition

${ }^{31}$ During the period under discussion here, the elites of Ljubljana and Trieste often failed to establish successful cooperation. This had a further negative impact on the integration of the Slovenian community, meaning that Vienna became the focus for efforts to gain support for Slovenian liberation.

${ }^{32}$ This is discussed, primarily with reference to the Italian-language press published in Trieste, in Štefan Čok, 'Slovensko-italijanski in hrvaško-italijanski odnosi preko poročanja tržaških časopisov 1866-1882', Acta Histriae, xx, 1-2 (2012), 189-210. It is quite obvious, but nevertheless bears repeating, that the sense of threat was a result of the unification of the Kingdom of Italy and its goal of uniting all lands inhabited by Italian populations.

${ }^{33}$ Compare Lewis Coser, The Functions of Social Conflict (London, 1956). 
over resources, this rivalry produces a sense of distance and mutual isolation between them. As Wnuk-Lipiński argues, "associations [emerge] that come to function in isolation from their surroundings while internally, they are bound by powerful emotional bonds". ${ }^{34}$ Seen in this context, the task of local elites becomes clearer. Leading figures, such as Nabergoj, were expected to serve as engaged role models, with the habitus of elites demonstrating a readiness to become active participants in public life, closing the gap between the private and public spheres while at the same time placing heavy demands on one's time. This kind of engagement was rewarded by the group. It is necessary, though, to examine more closely how such engagement translated into actual group cohesion and involvement in political praxis.

In 1891, seventeen years into the existence of the Edinost association, an article appeared that discussed its activities. The text stressed its significance as a political organisation, its importance in the struggle to defend the interests of the entire nation, and the necessity for active involvement. Edinost received praise for the effectiveness and dedication of its chairman and board members, although it lamented that it was difficult, despite the engagement of those involved, to pinpoint the organisation's successes. The editors justified this situation, arguing that:

the indifference of our people in the Littoral poses a barrier to the effective work of the association, which might, in different circumstances, be expected to achieve significant results. The association has shamefully few members, with the majority of them being indifferent and inactive. This cannot go on because a great many tasks await the association in the near future. ${ }^{35}$

The critical assessment of the situation within the group is quite evident here. Despite activists' involvement (as the text itself states, "the members of the board are hardworking people who fulfil their duties conscientiously"), the majority of people were passive. On the one hand, the Slovenians' circumstances were framed primarily by an Italian threat, while on the other it was clear that what was lacking was an urge to consolidate the group internally and to participate

${ }^{34}$ Edmund Wnuk-Lipiński, Socjologia życia publicznego (Warszawa, 2008), 175.

35 'Politično društvo Edinost', Edinost, xvi, 2 (1891), 1. 
in mechanisms that would lead to strengthening its position in the political field. What is difficult to establish is the actual impact of the elites on mobilising members of the group that they represented. In light of the editors' assessment cited above, it can be assumed that Slovenians enjoyed the political benefits that mostly affected everyday life, such as Slovenian-language education and supporting credit societies that targeted Slovenian inhabitants of the Littoral, while proving unwilling primarily to participate in long-term political activities. More research would be required to establish the outcome of this fairly typical disparity between the ethos of the elite and the attitudes of the rank-and-file members of the group, and whether it was partly a result of the discrepancies between the visible Italian-Slavic animosity that was presented in and fuelled by media discourse on the one hand, and everyday practices that enabled cross-cultural contact and cooperation, on the other.

The situation changed at the turn of the twentieth century when a younger generation entered the public sphere, with a more broadly Southern Slavic rather than exclusively Slovenian political movement gaining in strength and prominence. In 1905, Josip Smodlaka, a Croatian politician from Dalmatia, praised the activism of the Slovenians from Trieste who, in his view, were "the poorest among poor nations" yet still fought for national institutions and diligently laid the foundations for a national life in Trieste. ${ }^{36}$ Smodlaka gave his speech a year after the opening of the National Hall (Narodni dom) in Trieste, which stood in the centre of the city and housed Slovenians' most important social institutions (a theatre, a bank, the Edinost society, a reading room, the offices of the Sokol sports association, and others). The National Hall was also a visible symbol of the Slovenian presence, both literally and metaphorically, and that right at the heart of the city. ${ }^{37}$ Generally, institutions like Narodni dom were formed of multifunctional buildings that housed institutions that were important to national life on the local level. In the territories inhabited by Slovenians, a Narodni dom was established in the towns and cities of Celje (1897), Maribor (1898) and Ljubljana (1896), with the Trieste institution later joining the others

36 'Govor Josipa Smodlake', Narodna misao, iii, 38 (1905), 1-2.

${ }^{37}$ For more on the significance of the building and the activities carried out there, see Marko Korošič, 'Fabijanijeva slovenska domova v Trstu in Gorici', Arhitektura in urbanizem, xxi, 6 (2015), 59-64. 
as a symbol of Slovenian presence in the territory the community considered its own. ${ }^{38}$

In 1901, the Društvo Narodni dom v Trstu (Society for a National Hall in Trieste) was established by leading representatives of the local Slovenian elites, with the Croatian activist Matko Mandić as the chairman. He was also chairman of Edinost at the time. ${ }^{39}$ Others involved were Edvard Slavik, Gustav Gregorin (treasurer), Josip Abram, Otokar Rybár and Ante Bogdanović. ${ }^{40}$ It is also important to note the broader Slavic context in which the Slovenian political activists' efforts were situated. This was evident primarily in the readiness to cooperate with Croatians (and to a lesser degree Serbs) who lived in the Austrian Littoral. They were mainly in Istria, but there were some in Trieste too. The Society for a National Hall in Trieste issued an appeal that was addressed to 'Slavs in Trieste and environs' and began with the words: "To those of you who live amid the struggle against our powerful enemies, to those of you who yourselves are leaders and soldiers in this struggle, there is no need to explain that a Narodni dom is of crucial significance for the Slovenians of Trieste". ${ }^{41}$ The local-level political cooperation between Croatians and Slovenians should undoubtedly be seen in terms of being a forerunner of the common position that would be adopted in the Imperial Council and the programme for political emancipation that emerged and was promoted under the Yugoslavian banner. However, my analysis of Trieste-based journalism views the appeal to the Slavic community principally as a call to the Slovenian community. It was a way of stressing the importance of the national movement and its significance for all Slavs, rather than seeing it as something limited to the local level or Slovenians only. "The great significance of the city of Trieste

38 See Milan Pahor, 'Zrno do zrna, pogača, kamen do kamna, palača! Društvo “Narodni dom” v Trstu 1900-2000', Zgodovinski časopis, liii, 3 (1999), 333-4.

${ }^{39}$ Matko Mandić belonged to the younger generation of Croatian activists in Istria who abandoned the exclusivism of the Party of Rights (HSP) and sought to collaborate with Slovenians in their common struggle against Italian domination. Between 1897 and 1905 he served as the chairman of the Edinost association and thus cooperated closely with Slovenian politicians. See Salvator Žitko, 'Slovenskohrvatski odnosi u Austrijskom primorju u kontekstu "novoga kursa” hrvatske politike 1903-1907', Histria, vi, 6 (2016), 59-92.

40 'Slovani v Trstu in okolini!', Edinost, xxvi, 134 (1901), 1.

41 Ibid. 
for Slavs, in particular, Slovenians", was, according to it editors, the raison d'être for a new periodical published in a city at the peripheries of the Slavic lands. ${ }^{42}$ Published in Ljubljana, Kmetijske in rokodelske novice wrote in similar terms, seeing the Narodni dom in Trieste as an institution that was of national significance while establishing a Slavic centre on the Adriatic. ${ }^{43}$ Its location 'in the threatened borderlands' 44 was often stressed, with this phrase underlining the imperative for activism and engagement.

Slavic identity was promoted as a way of underpinning emergent national identities. Given the dearth of social capital and the low status of the local Slovenian population, a sense of belonging to the great Slavic community could provide a counterbalance to Italian aspirations, which were grounded in a perceived cultural superiority. In the early nineteenth century, Italians perceived the Slovenians as a mostly rural population that was lacking in elites and coherence. National activists were aware of this situation and sought to generate an emancipatory discourse, with one of its essential traits being belonging to Slavdom. This offered two advantages: differentiation from the Italians; and laying strong foundations for the articulation of political aspirations, hence belonging to Slavdom as a dimension of Slovenianness was often stressed in texts published in Edinost.

\section{VI}

\section{THE HABITUS OF LOCAL LEADERS}

The trajectory of Ivan Nabergoj's life can be considered as an exemplary symbolic illustration of the political advance of the local Slovenian community. He went from the provinces to the urban centre of the region, from a peasant farm to the city council, and then on to the most important state institutions, with his hard work and perseverance ensuring that his primary education was no barrier to becoming a public figure of authority. It is also worth turning briefly to the biographies of the other signatories of the founding document of the Society for a National Hall in Trieste, as they were, alongside Nabergoj, the most influential figures in the Slovenian national movement in Trieste.

42 'Program', Edinost, i, 1 (1876), 1.

43 'Za "Narodni dom” v Trstu', Kmetijske in rokodelske novice, lix, 36 (1901).

44 'Ne razumejo nas!', Edinost, xxvi, 210 (1911), 1. 
The life of Otokar Rybár (1865-1927) offers another interesting illustration of a biography formed in the Habsburg Empire, as it is marked by numerous transethnic and transregional connections, as well as illustrates the complexities associated with the mobility of the elites. Rybár was born in Postojna to a Czech father and a Slovenian mother. ${ }^{45}$ In contrast to Nabergoj, he was from the middle class, as his father was a railway engineer and thus as a technician had a certain social standing. Rybár completed advanced secondary education at a grammar school in Vienna (where he had moved together with his family) and then studied law. He was awarded a doctorate in law in 1889, and then started his legal career at the district court in Trieste before working at a law firm in Pazin, Istria, followed by a post in Sežana (Sesana), near Trieste. In 1895 he opened his own law firm in Trieste, becoming the third Slovenian lawyer in the city. From the moment he arrived, he was actively engaged in public life, getting involved in all the most important Slovenian institutions in the city. He served on the board of the Edinost society, including acting as chairman between 1907 and 1910, of the Slavjanska čitalnica (Slavic Reading Room), and the Sokol organisation, where he was also deputy district head of the Slovenian Sokol Association (Slovenska sokolska $z v e z a$ ). He was also one of the co-founders of Jadranska banka (Adriatic Bank) and Splošna hranilnica (General Savings Bank) in Trieste. He was also active in politics, serving on the city and provincial councils between 1900 and 1914, while he was twice elected to the Imperial Council, in the general elections of 1907 and 1911.

Rybár's career is indicative of a further stage of evolution in the development of the Slovenian national movement. It could be argued that on the local level he was the successor to Nabergoj. Peter Rustja offers a particularly interesting insight in arguing that "during the initial period of the association's activities in the Trieste district, when peasants and farmers played a leading role, the leadership of Edinost adopted noticeably bourgeois traits. The leadership also included the lawyer Otokar Rybář". ${ }^{46}$ The new recruits came primarily from

${ }^{45}$ The biographical information is taken from: Rudolf Andrejka and Lavoslav Čermelj, Rybáŕ Otokar, Slovenski biografski leksikon, https://www.slovenska-biografija.si/ oseba/sbi530001/ [Accessed: 18 Aug. 2019]; Peter Rustja, Otokar Rybáŕ v dunajskem parlamentu, i (Trst, 2001), 13-22.

${ }^{46}$ Rustja, Otokar Rybáŕ v dunajskem parlamentu, 46. 
engineers and those in the free trades. Alongside the construction of the Narodni dom, this was another sign of the growing presence of the Slovenian community in the city and thus of its rising status and growing social affirmation. Nevertheless, the habitus of the elite remained unchanged. As in the case of Nabergoj, there was an evident ethos that demanded participation in public life, generating an imperative to work for the good of the community, and thus combine professional and political duties. What was also clear was that this meant having a limited private life, as one's free time was dedicated to public service.

Josip Abram (1865-1952) was born in Trieste to a family of wood traders and coopers. His life followed a similar path to that of Rybár and was typical of children from aspirational middle-class families who sought to improve their social standing. Abram completed advanced secondary education at a grammar school in Trieste and also then studied law in Vienna. ${ }^{47} \mathrm{He}$ was awarded a doctorate from Graz before qualifying as a lawyer in Trieste in 1898. He then worked for Otokar Rybár's law firm. Like the other figures discussed here, he was actively involved in public life as he sought to improve the status of the Slovenian community, concentrating his activities on the realm of education. He was involved in the Trieste branch of Družba sv. Cirila in Metoda (The Society of SS. Cyril and Methodius), with his efforts playing a significant part in the construction of a modern Slovenian school, St Jacob's. He was also actively involved in the work of the savings and credit society and, as mentioned above, was one of the founders of the Society for a National Hall in Trieste. He served on the Trieste city and provincial councils from 1910 to 1914. There were many other Slovenian organisations that he was involved in which are not mentioned here.

Another member of the elite involved in Edinost was Edvard Slavik (1865-1931). He was born in Prosek (now Prosecco) to a Czech father and Slovenian mother. ${ }^{48} \mathrm{He}$ also studied law in Vienna and served his legal apprenticeship at the law firm of Gustav Gregorin,

${ }^{47}$ Abram's biographical information is taken from: Barbara Šterbenc Svetina (ed.), Novi slovenski biografski leksikon (Ljubljana, 2013), 22-3.

${ }^{48}$ Biographical information taken from: Tomaž Marušič, 'Šest znamenitih tržaških odvetnikov in politikov', Odvetnik. Glasilo Odvetniške zbornice Slovenije, iii, 5 (2001), 37; Vaso Suyer, 'Edvard Slavik', Slovenski biografski leksikon (2013), https://www. slovenska-biografija.si/oseba/sbi582724/ [Accessed: 16 Aug. 2019]. 
for whom he later worked. Slavik was a member of the board and secretary of Edinost, and later served as deputy chairman. He was chairman of the Edinost printing house and head of Pevsko in glasbeno društvo $v$ Trstu (The Singing and Musical Society of Trieste). As an Edinost candidate he was elected four times to the city and provincial councils (in 1903, 1906, 1909 and 1913).

\section{VII \\ CONCLUSIONS}

Given that the above biographies are representative of the local elites at the turn of the twentieth century, it can be seen that a common trait shared by all of the Slovenian community leaders in Trieste was that they placed great emphasis on organisation. Each of those mentioned was active in various fields of the public sphere as they contributed to the formation of institutions for the local Slovenian community. It is this institutionalisation of national life through the creation of infrastructures for the group that constituted one of the most important aspects of the elites' activities. Another significant element of their work was that they came to be seen as role models embodying the virtues ascribed to their group as they developed ideal-type biographies. While personal achievements were significant, successes in the realm of institutionalisation was the common goal of all of the men mentioned above. They adopted a wide variety of practices aimed at ensuring that all the key fields of activity acquired strong institutional foundations while serving the national cause. Thanks to this, the group that they represented had a clear framework for its activities, and thus its successes could expand exponentially once the basic foundations had been laid. This meant that a group that once enjoyed low social standing and had little coherence could acquire political, social and economic capital while reaffirming its status as a political community. It should also be stressed that the abovementioned activists made a conscious effort to be active within their 'we-group', i.e. among Slovenians. They offered mutual support, as became evident in their professional activities and their efforts to develop a group of Slovenian lawyers in Trieste. What was specific about the Slovenian case was the significance of the local dimension. Because the Ljubljana community was not effective in transmitting its efforts to other parts of the Slovenian lands, this opened up an opportunity for 
local elites to become the most important representatives of Slovenian group interests.

The situation examined here highlights the local dimensions of nation-building within the political communities that formed in the Habsburg Empire during the constitutional period. I would argue, following Manuel Castells, that nations can be understood as "cultural communes constructed in people's minds and collective memory by the sharing of history and political projects". ${ }^{49}$ Thus in this article, I have stressed the political dimension and the way the local Slovenian community both ensured internal consolidation while remaining outwardly active in dealing with conditions that saw competition over status and resources. Since the greater part of social experience is, as Castells has outlined extensively, ${ }^{50}$ determined locally, what becomes crucial is the work of community leaders who establish models of participation and create the language of public discourse. What became evident in Trieste was a division of social space along ethnic lines because it was cultural attributes (language, customs and history) that were employed in efforts to legitimise the political aspirations and objectives.

Analysis of the discourse and activities of the Slovenian political elites in Trieste reveals that local identity was built around a sense of resistance, with the national dimension providing much support in this respect. Further research could examine and demonstrate how and why the competing projects of a supra-ethnic nature proved unsuccessful. I have in mind, first and foremost, the socialist movement, whose activists failed to ensure that Italian and Slovenian workers coalesced around a common cause. It thus seems that the activities of local elites were crucial to nation-building.

proofreading James Hartzell

${ }^{49}$ Manuel Castells, The Information Age: Economy, Society, and Culture, ii: The Power of Identity (Malden, MA-Oxford, 2004²), 54.

50 See Castells, The Information Age, ii, 63 ff. 


\section{SELECTED BIBLIOGRAPHY}

Bourdieu Pierre, Language and Symbolic Power, trans. Gino Raymond and Matthew Adamson (Oxford, 1990).

Cetnarowicz Antoni, 'Słoweńskie programy narodowe do roku 1914', Prace Komisji Środkowoeuropejskiej PAU, i (1993), 35-50.

Cetnarowicz Antoni, 'Zjednoczona Słowenia. Z problematyki słoweńskiego ruchu narodowego w połowie XIX wieku', Balcanica Posnaniensia, vi (1993), 23-37.

Čok Štefan, 'Ivan Nabergoj, the "Never to Be" Mayor of the Slovenes in Trieste (1873-1897)', Studia Historica Slovenica, xvii, 1 (2017), 65-84.

Čok Štefan, 'Slovensko-italijanski in hrvaško-italijanski odnosi preko poročanja tržaških časopisov 1866-1882', Acta Histriae, xx, 1-2 (2012), 189-210.

Falski Maciej, 'Czytanie i ontologia narodu. Chorwacki i słoweński ruch czytelniany w drugiej połowie XIX wieku', in Ewa Łukaszyk and Krystyna Wierzbicka-Trwoga (eds), Niewtasne lektury. Od pisarstwa w jezyku wyuczonym do wielości kultur czytania (Warszawa, 2018), 95-114.

Falski Maciej, 'Semiotics of the "Third Force" MOST and the Performative and Visual Dimension of Political Life in the Post-electoral Period in Croatia, 2015', Narodna umjetnost, lvi, 1 (2019), 27-40, https://doi.org/10.15176/vol56no102.

Grafenauer Bogo et al. (eds), Zgodovina Slovencev (Ljubljana, 1979).

Jurčević Josip, 'Upravljačke elite u suvremenoj hrvatskoj povijesti', in Drago Čengić and Ivan Rogić (eds), Upravljačke elite i modernizacija (Zagreb, 2001).

Matić Dragan, Nemci v Ljubljani 1861-1918 (Ljubljana, 2002).

Pletikosić Ivica, 'Revizije prebivalstva Tresta iz leta 1910', Annales. Serie Historia et Sociologia, xvi, 2 (2006), 477-82.

Rahten Andrej (ed.), Tvorci slovenske pomorske identitete (Ljubljana, 2010).

Rustja Peter, Med Trstom in Dunajem. Ivan Nabergoj $v$ avstrijskem državnem zboru (1873-1897) (Trst, 1999).

Rustja Peter, Otokar Rybáŕ v dunajskem parlamentu, i (Trst, 2001).

Šterbenc Svetina Barbara (ed.), Novi slovenski biografski leksikon (Ljubljana, 2013).

Vrišer Igor, Razvoj prebivalstva na območju Ljubljane (Ljubljana, 1956).

Wnuk-Lipiński Edmund, Socjologia życia publicznego (Warszawa, 2008).

Žitko Salvator, 'Slovensko-hrvatski odnosi u Austrijskom primorju u kontekstu “novoga kursa” hrvatske politike 1903-1907', Histria, vi, 6 (2016), 59-92.

Maciej Falski - urban spaces in anthropology and social history frameworks, and social imaginaries in the public sphere, particularly in the Southern Slavic and Balkan regions; assistant professor at the Institute of Western and Southern Slavic Studies, University of Warsaw; Head of the Post-Yugoslav Area Research Centre (PROP, http://prop.uw.edu.pl/); e-mail: mf.falski@gmail.com 